- FINANSE I PRAWO FINANSOWE.

- Journal of Finance and Financial Law •

Czerwiec/June 2020 • vol. 2(26): 129-144

https://doi.org/10.18778/2391-6478.2.26.09

\title{
WPŁYW FORMUŁY IN-HOUSE \\ NA EFEKTYWNOŚĆ ZAMÓWIEŃ UDZIELANYCH PRZEZ ADMINISTRACJĘ SAMORZĄDOWA
}

\author{
Jarosław Szymański \\ Wydział Ekonomiczno-Socjologiczny, Uniwersytet Łódzki \\ ORCID: https://orcid.org/0000-0003-2166-145X
}

\begin{abstract}
Streszczenie
W roku 2017 krajowy systemu zamówień publicznych został wzbogacony o nową formułę poszerzającą wachlarz wyłączeń ustawowych, określaną jako zamówienia in-house. Jest to nowa przesłanka upoważniająca do odstąpienia zamawiającego od zastosowania procedur przetargowych określonych prawem. Umożliwia ona zachowanie monopolu wykonawcy w obszarze zamówień udzielanych przez podmiot, który sprawuje nad nim kontrolę. Z uwagi na specyfikę formuły, która tworzy quasi zmonopolizowany rynek, przeprowadzono badanie w celu zidentyfikowania zmian konkurencyjności i efektywności udzielanych zamówień. Z uwagi na strukturę udzielanych zamówień $w$ formule in-house, skoncentrowano się na usługach odbioru i zagospodarowania odpadów. Zidentyfikowano zmiany na rynku badanych usług, które wywołało zastosowanie formuły. W pracy zastosowano podejście badawcze oparte na danych ilościowych publikowanych w systemie zamówień publicznych.
\end{abstract}

Słowa kluczowe: zamówienia publiczne, klauzule społeczne, zamówienia in-house.

JEL Class: K49, H57, H68. 


\section{WSTĘP}

W obrocie gospodarczym funkcjonują podmioty, realizujące zadania publiczne w oparciu o dwa różne modele działania. Pierwszy, dotyczący podmiotów prywatnych, w tym spółek opartych na zasadach określonych w Kodeksie Spółek Handlowych, które muszą koncentrować swoją uwagę na mechanizmach wolnorynkowych oraz drugi, dotyczący podmiotów publicznych, dla których określono administracyjne mechanizmy postępowania, w tym wydatkowania środków finansowych. Zgodnie z obowiązującymi regulacjami prawnymi, możliwość realizowania zamówień publicznych nie jest ograniczona strukturą właścicielską potencjalnego wykonawcy.

Sektor prywatny jest weryfikowany poprzez mechanizmy rynkowe, których jedną z podstawowych zasad jest utrzymanie płynności finansowej, a podstawowym celem jest dążenie do uzyskania jak najkorzystniejszej różnicy między przychodami i wydatkami. Nieumiejętne zarządzanie podmiotem prywatnym skutkuje jego likwidacją, na ściśle określonych zasadach, wynikających z charakteru prawnego podmiotu. W odróżnieniu od sektora prywatnego, efektywne zarządzanie finansami publicznymi, szczególnie podmiotów prowadzących działalność gospodarczą, jest trudne w ocenie. Konieczność dostosowania się do dodatkowych administracyjnych wymogów, brak mechanizmów rynkowych zapewniających optymalne wykorzystanie zasobów, orientacja na cele społeczne, mają bezpośredni wpływ na wynik finansowy, co w konsekwencji determinuje oferowane warunki realizacji zamówienia. W praktyce oznacza to, że podmiot publiczny może realizować zamówienie w oderwaniu od realiów rynkowych.

Do roku 2017, unijną zasadą wydatkowania środków publicznych, niezależnie od struktury właścicielskiej podmiotu realizującego zamówienie, była konkurencyjna gra potencjalnych wykonawców w oparciu o zasady określone w Dyrektywach UE, implementowane w ustawodawstwach krajów członkowskich. Realizację zamówienia otrzymywał podmiot oferujący zamawiającemu najkorzystniejsze warunki. Każdy z potencjalnych wykonawców musiał, kalkulując cenę oferty, ustalić cenę rynkową $\mathrm{w}$ oparciu o koszty własne oraz potencjalną liczbę konkurentów. W takich warunkach wykonawca będący podmiotem publicznym, chcąc skutecznie funkcjonować na rynku zamówień publicznych musiał być tak konkurencyjny jak podmioty o kapitale prywatnym.

W roku 2017 nastąpiła zmiana w unijnym prawodawstwie, umożliwiająca udzielanie zamówień publicznych typu in-house poprzez wykorzystanie trybu zamówienia z wolnej ręki podmiotom prowadzącym działalność gospodarczą z kapitałem publicznym. Oznacza to w praktyce wyłączenie konkurencji na obszarze wyznaczonym przez zamawiającego i realizację zadania przez podmiot publiczny, skutkując przyjęciem warunków realizacji zamówienia odbiegających od realiów rynkowych. 
Ograniczenie konkurencyjności poprzez uprzywilejowywanie wybranych podmiotów, oddziałuje na rynek w dwojaki sposób. Po pierwsze wyłącza całkowicie konkurencyjność w obszarze wybranym przez wykonawcę, któremu udzielono zamówienia $\mathrm{w}$ trybie $\mathrm{z}$ wolnej ręki, po drugie ogranicza konkurencyjność poprzez brak aktywności wykonawców z kapitałem publicznym nasyconych zamówieniami uzyskanymi w trybie niekonkurencyjnym. Celem pracy jest ocena zmian w efektywności i konkurencyjności na rynku usług odbioru i zagospodarowania odpadów po wprowadzeniu formuły in-house. Postawiono hipotezę, że wprowadzone zmiany legislacyjne obniżyły konkurencyjność rynku i efektywność ekonomiczną udzielanych zamówień.

Analizę przeprowadzono w oparciu o próbę losową, wykorzystując narzędzia statystyki matematycznej. Dane pobrano z serwera administrowanego przez Urząd Zamówień Publicznych.

\section{EFEKTYWNOŚĆ ZAMÓWIEŃ PUBLICZNYCH I KLAUZULE SPOŁECZNE}

Samo pojęcie efektywności jest bardzo szerokie, a w literaturze dotyczącej zamówień publicznych doczekało się wielu definicji. W analizach dotyczących systemu zamówień publicznych pojęcie efektywności ujmowane jest w dwóch wymiarach, finansowym oraz sprawności prowadzenia procedury [Nowicki 2013: 10]. Dokonując ich syntezy można stwierdzić, że efektywne zamówienia publiczne to takie, w których za określoną kwotę otrzymujemy maksimum korzyści pierwszo i drugoplanowych lub otrzymujemy daną korzyść za możliwie najniższą cenę rynkową [Szymański 2016: 513]. Rozbudowując powyższą definicję należy doprecyzować znaczenie korzyści w zamówieniach publicznych. Zamówienie publiczne ma na celu realizację bezpośrednich potrzeb podmiotu, które stanową cel pierwotny, tak zwaną korzyść podstawową oraz, o ile to możliwe, realizację celów drugorzędnych, niekoniecznie związanych z celem pierwotnym, stanowiących korzyści wtórne, których charakter może daleko odbiegać od materii przedmiotu zamówienia określonego w ogłoszeniu i Specyfikacji Istotnych Warunków Zamówienia (SIWZ).

Obserwacja funkcjonowania systemów zamówień publicznych krajów europejskich, azjatyckich i Stanów Zjednoczonych Ameryki Północnej wskazuje na możliwość uzyskiwania realnych drugorzędnych korzyści, na przestrzeni określonego czasu, które z racji skali stanowią niejednokrotnie niekwestionowaną wartość. Przykładem są efekty programu Energy Star, dzięki któremu uzyskano w latach 1992-2018 w samych Stanach Zjednoczonych oszczędności energetyczne na poziomie $4000 \mathrm{TWh}$ oraz zmniejszono emisję gazów cieplarnianych o ponad 3 miliardy ton, co odpowiada rocznej emisji ponad 600 milionów samochodów [www1, dostęp 18.03.2020]. Zaznaczyć należy, że nie istnieje narzędzie 
umożliwiające oszacowanie wartości ekonomicznej celów wtórnych na etapie udzielania zamówienia. Efekty wprowadzenia wymogu podwyższenia standardu energooszczędności przez administrację amerykańską są spektakularne, ale z perspektywy wieloletnich obserwacji.

Celami wtórnymi zamówienia publicznego może być aktywizacja osób wykluczonych zawodowo lub bezrobotnych, wpieranie innowacyjności gospodarki, działania proekologiczne, przynosząc istotne, ale trudno wymierne korzyści społeczne i ekonomiczne. Przykładem możliwości, jakie dają zamówienia publiczne w stymulowaniu zachowań wykonawców, obok wskazanych powyżej efektów ekologicznych jakie daje obniżenie energochłonności wyrobów, jest pobudzanie wykonawców do kreowania nowych jakościowo rozwiązań technicznych. W praktyce zamawiający mogą kreować cele wtórne, między innymi poprzez stosowanie pozacenowych kryteriów oceny ofert. Dodatkowo, w celu zwiększenia udziału zamówień, które nie koncentrują się wyłącznie na realizacji podstawowego zamówienia, krajowe regulacje prawne umożliwiają zastosowanie dedykowanego trybu udzielania zamówień, którym jest partnerstwo innowacyjne.

Od początku roku 2010 wprowadzono nowelizacją ustawy Pzp możliwość stosowania tzw. klauzul społecznych [www3, dostęp 15.02.2020], których wachlarz z kolejnymi nowelizacjami konsekwentnie był poszerzany, umożliwiając wprowadzanie przez zamawiających wymogów dotyczących zatrudnienia przez wykonawcę do realizacji zamówienia m.in. osób bezrobotnych, młodocianych w celu przygotowania zawodowego, osób niepełnosprawnych [Nowicki 2018: 68]. Zamawiający uprawniony jest do obniżenia konkurencyjności procedury, także poprzez ograniczenie kręgu potencjalnych wykonawców np. do podmiotów, u których ponad 50\% zatrudnionych pracowników stanowią osoby niepełnosprawne.

W praktyce udzielania zamówień publicznych powstaje obszar decyzyjny, zależny wyłącznie od kierownictwa podmiotu wszczynającego zamówienie (z wyjątkiem wybranych jednostek administracji rządowej) ${ }^{1}$, w którym trzeba określić, obok wymaganych ustawą czynności, zakres oddziaływania zamówienia na otoczenie gospodarczo-społeczne. Należy jednak stwierdzić, że brak aktywności zamawiającego w powyższym temacie, poza nielicznymi wyjątkami, i w efekcie ograniczenie się do podjęcia wyłącznie działań prowadzących do realizacji celu podstawowego, nie wpływa na ocenę pracy osób kierujących podmiotem i nie jest monitorowane przez system zamówień publicznych.

Realizacja celów wtórnych zamówienia publicznego wiąże się z koniecznością poniesienia dodatkowych kosztów, może obniżyć konkurencyjność postępowania oraz w przypadku bardzo wysublimowanego zamówienia lub sposobu jego realizacji może doprowadzić do unieważnienia procedury z uwagi na brak ofert.

${ }^{1}$ Zalecenia w sprawie stosowania przez administrację rządową klauzul społecznych w zamówieniach publicznych przyjęte przez Radę Ministrów 28 lipca 2015 r. 
Sytuacja, w której dochodzi do unieważnienia jest prawdopodobna z uwagi na niską konkurencyjność w zamówieniach publicznych, liczoną liczbą złożonych ofert na postępowanie, która w roku 2018 wynosiła przeciętnie 2,3 oferty/zamówienie [UZP 2017: 41]. Z prowadzonych badań w wybranych obszarach zamówień publicznych wynika, że spadek konkurencyjności prowadzi do zwiększenia kosztów realizacji zamówienia publicznego [Szymańska i Szymański 2019: 320]. Jednym z najważniejszych elementów skupiających uwagę kierownictw podmiotów prywatnych i publicznych są finanse, przy zasadniczej różnicy w kryteriach ich oceny. Dla podmiotów prywatnych ocena racjonalności wydatkowania środków finansowych jest dokonywana wyłącznie z punktu widzenia danego podmiotu. W odróżnieniu, ocena podmiotu publicznego może być prowadzona w kilku płaszczyznach, a czynnikiem wyróżniającym jest rodzaj podmiotu publicznego. Większość literatury światowej obejmującej problematykę zamówień publicznych dotyczy oceny strategii podejmowanych działań z perspektywy zamawiającego [Murray 2009: 91-103].

W krajowej praktyce występują zasadniczo dwa rodzaje podmiotów publicznych, a o podziale decyduje sposób ich finansowania. Pierwsze to instytucje, których działalność praktycznie w całości finansowana jest środkami publicznymi, a ewentualne dodatkowe przychody, najczęściej z działalności usługowej, są znikomo małe, np. jednostki administracji samorządowej. Drugie to instytucje publiczne działające w obszarze wolnego rynku, takie jak np. szpitale miejskie, kliniczne lub wojewódzkie, które mogą być wspierane bezpośrednio środkami publicznymi w formie np. dotacji, ale samodzielnie ponoszą główny ciężar działalności w oparciu o środki zdobywane na równych zasadach z podmiotami prywatnymi.

Efektywność gospodarowania finansami jest różnicowana sposobem finansowania podmiotu, co bezpośrednio wpływa na racjonalność rozłożenia nacisku na osiąganie celów drugoplanowych. W zależności od rodzaju zamawiającego, każde zamówienie powinno być poprzedzone analizą celowości zwiększenia jego oddziaływania na przestrzeń społeczno-gospodarczą, tak aby pieniądze publiczne były wydatkowane optymalnie. W takim przypadku instytucja publiczna, która ponosi np. koszty związane ze wsparciem osób bezrobotnych, powinna w ogłaszanych zamówieniach dotyczących robót budowlanych lub usług uwzględnić kryteria społeczne, które mogą w pewien sposób oddziaływać na zwiększenie ceny ofert składanych przez wykonawców. W ostatecznym rozrachunku wzrost ceny oferty będzie skompensowany spadkiem kosztów utrzymania np. osób bezrobotnych. Pomimo że temat jest istotny z punktu widzenia finansów publicznych, nie są prowadzone badania w kierunku oszacowania potencjalnych korzyści budżetowych.

Odmienne postrzeganie efektywnego wydatkowania środków finansowych będą miały np. szpitale publiczne, które są skoncentrowane na obniżaniu kosztów, poprzez m.in. uzyskiwanie możliwie najniższych cen ofert w prowadzonych postępowaniach o udzielenie zamówienia. Ma to szczególne znaczenie, ponieważ 
wydatki na zamówienia publiczne tych podmiotów stanowią łącznie około 50\% ich rocznego budżetu [Szymański 2016: 518]. W tym przypadku, dodatkowa koncentracja zamawiającego na efektach drugoplanowych, które nawet w sposób symboliczny nie wpłyną na jego sytuację finansową, w perspektywie zwiększenia kosztów działalności podstawowej, do której podmiot został powołany, wydaje się nieracjonalna. Podsumowując, nie można oczekiwać, że szpital publiczny będzie wprowadzał np. klauzule, społeczne pomimo że ich stosowanie w konsekwencji obniża koszty funkcjonowania systemu zdrowia. Wzrost kosztów wynika ze specyfiki krajowego systemu ubezpieczeń zdrowotnych, który zapewnia bezpłatne leczenie szpitalne, natomiast leczenie ambulatoryjne wymaga poniesienia kosztów zakupu leków. Osoby bezrobotne, których nie stać na wykupienie leków, w stanie zaostrzonym schorzenia są hospitalizowane i leczone nieodpłatnie. Nie zmienia to jednak sytuacji szpitala, ponieważ zwiększone koszty przenoszone są na Narodowy Fundusz Zdrowia, a szczegółowych analiz problemu nikt nie prowadzi.

Podsumowując, postrzeganie efektywności wydatkowania środków finansowych przez zamawiających, jest uwarunkowane zarówno źródłem finansowania, jak i zakresem obowiązków podmiotu publicznego. Im szerszy obszar działalności, tym większa możliwość wykorzystania zamówień publicznych ukierunkowanych na dodatkowe, wtórne efekty. Koncentracja na wąskim odcinku działalności taką aktywność w praktyce wyklucza, podobnie jak ograniczone środki finansowe.

Z kontroli prowadzonych przez NIK wynika, że klauzule społeczne wprowadzały samorządy, najczęściej w ramach umów zawieranych na realizację robót budowlanych i odbiór odpadów komunalnych, co przedstawiono na wykresie 1 [www2, dostęp 8.02.2020]. Nie odnaleziono innych źródeł danych dotyczących struktury zamówień wykorzystujących klauzule społeczne.
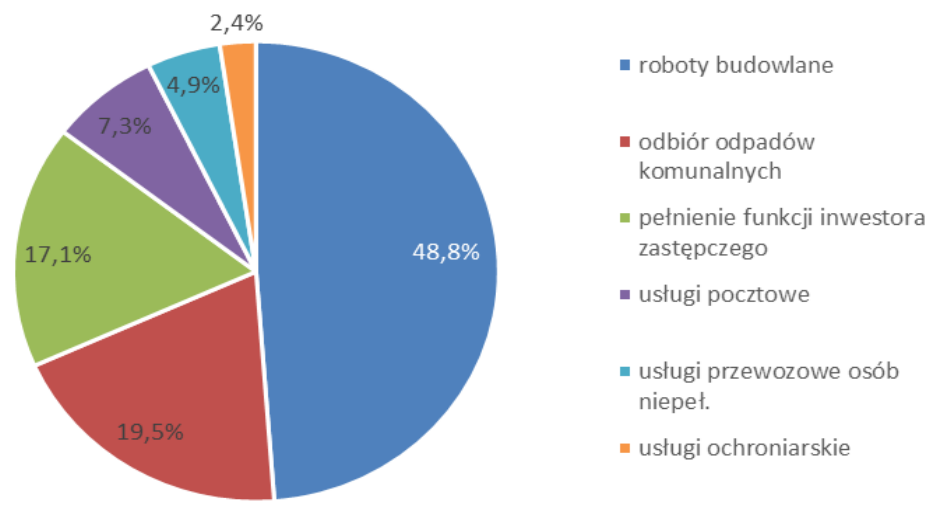

Wykres 1. Struktura zamówień udzielanych przez samorządy, zawierających klauzule społeczne w latach 2013-2016

Źródło: NIK, https://www.nik.gov.pl. 


\section{ZAMÓWIENIA IN-HOUSE W PRAKTYCE KRAJOWEJ}

Administracyjne zasady udzielania zamówień mają zapewnić obiektywizm przy wyborze najkorzystniejszej oferty i w konsekwencji bezstronny wybór wykonawcy realizującego zamówienie. Zapewnienie obiektywizmu w procedurze udzielania zamówienia sprowadza się do zachowania zasad uczciwej konkurencji i równego traktowania wykonawców przy pełnej transparentności prowadzonej procedury [Pokrzywniak i in. 2006: 6]. Zasada zachowania uczciwej konkurencji w zamówieniach publicznych zakazuje faworyzowania nie tylko określonych podmiotów, lecz nawet oferowanych przez nich dóbr, czego konsekwencją jest zakaz stosowania nazw własnych w opisie przedmiotu zamówienia [Andała-Stępkowska i Bereszko 2018: 44].

W celu udzielenia zamówienia podmiot publiczny, co do zasady, zobowiązany jest do wyboru konkurencyjnego trybu udzielenia zamówienia, i w zależności od wartości szacunkowej zamówienia, upublicznienie informacji o zamówieniu w Biuletynie Zamówień Publicznych zamieszczonym na portalu Urzędu Zamówień Publicznych (UZP) lub w bazie Tenders Electronics Daily (TED) zamieszczonej na portalu Komisji Europejskiej. Wynika to z podziału zamówień w oparciu o ich wartość szacunkową na trzy grupy:

- zamówienia drobne, poniżej progu bagatelności określonym w wysokości 30 tys. euro,

- zamówienia biuletynowe, krajowe, które podlegają rygorom ustawy Pzp, ale nie są w obszarze regulacji unijnych, o wartościach wyższych od progu bagatelności i niższych od progów unijnych wyznaczonych Dyrektywami UE,

- pozostałe zamówienia, unijne, których wartość szacunkowa nie jest ograniczona kwotą maksymalną, procedowane zgodnie $\mathrm{z}$ zasadami określonymi w Dyrektywach UE i podlegające monitoringowi Komisji Europejskiej.

Zgodnie z obowiązującymi w roku 2020 regulacjami, próg bagatelności określa ustawa Pzp, kwoty progów, powyżej których zamówienie zostaje uznane za unijne są publikowane w Rozporządzeniu Ministra Rozwoju [Dz.U. 2019, poz. 2450] implementującym do krajowego systemu prawnego postanowienia Dyrektywy [2014/24/UE] wraz z rozporządzeniami zmieniającymi [UE 2019/1828]. Według nowych regulacji, które wejdą w życie w roku 2021, poszczególne progi ulegną nieznacznym modyfikacjom a zasada podziału pozostanie niezmieniona.

W ustawie Prawo zamówień publicznych (Pzp) [Dz.U. 2019 r. poz. 1843], regulującej zasady wydatkowania środków publicznych, jest także wymieniona enumeratywnie grupa zamówień wyłączonych spod jej rygorów. Dotyczy to np. usług arbitrażowych lub pojednawczych, zastępstwa procesowego, nabycia własności lub innych praw do istniejących budynków oraz wszystkich zamówień, których wartość szacunkowa nie przekracza progu bagatelności. Próg bagatelności ma za zadanie ułatwić pracę zamawiającym, poprzez zwolnienie ich 
$\mathrm{z}$ administracyjnych obowiązków przy drobnych zakupach i w konsekwencji obniżyć koszty działalności.

Sformułowanie in-house ma swoje źródło w orzecznictwie Europejskiego Trybunału Sprawiedliwości. Z uwagi jednak na brak jednoznacznych wytycznych stosowania formuły, wynikających ze specyfiki orzecznictwa, praktyka krajów członkowskich w powyższym zakresie bardzo się różniła. Brak precyzji w opisie przesłanek umożliwiających stosowanie nowej formuły skutkował zmianą art. 12 dyrektywy klasycznej 2014/24/UE, w której enumeratywnie wymieniono nowe przesłanki wyłączeń stosowania procedur ustawowych. Regulacje dyrektywy zostały zaimplementowane do ustawodawstwa krajowego ustawą z 22 czerwca 2016 r. [Dz.U. 2016 poz. 1020]. W praktyce od 1 stycznia 2017 r. ustawodawstwo krajowe $\mathrm{w}$ ramach formuły in-house umożliwia niekonkurencyjne, bezprzetargowe, udzielenie zamówień instytucjom publicznym, takim jak np. urząd miasta lub gminy, wykonawcy, dla którego jest podmiotem założycielskim, np. miejskim lub gminnym zakładom oczyszczania miasta. Pomijając szczegóły wprowadzonych przepisów, w tym określających procentowo zaangażowanie potencjału spółek zależnych w realizację zadań, wprowadzono możliwość wyłączenia konkurencji z udziału w zamówieniu i ustawienia wykonawcy publicznego na warunkach monopolistycznych, przy zamówieniach dotyczących robót budowlanych i całej palety usług. Taka pozycja, co do zasady, nie wpływa korzystnie na gospodarkę i sektor, w którym występuje. Jest dobra tylko dla monopolisty. Wyłączenie konkurencji umożliwia niekontrolowane przez rynek przeniesienie kosztów na odbiorcę dóbr lub usług, oferowanych przez monopolistę.

Zakres stosowania zamówień in-house można szacować korzystając $\mathrm{z}$ danych publikowanych przez UZP. Monitoring w tym zakresie możliwy jest pośrednio, zarówno w odniesieniu do zamówień o wartościach przekraczających progi unijne [UZP 2017: 34], jak i zamówień biuletynowych. Umożliwia to, realizowany przez zamawiających, ustawowy obowiązek przesyłania do Prezesa Urzędu informacji o wszczęciu postępowania w trybie zamówienia $\mathrm{z}$ wolnej ręki o wartości, która dla samorządów zamawiających dostawy lub usługi, w roku 2020, zaczyna się od równowartości kwoty 214 tys. euro (art. 67 ust. 2 Pzp). Ponadto wszystkie podmioty, które udzieliły zamówień, są zobligowane do składania rocznego sprawozdania, określającego szczegółowo: rodzaj, tryb oraz wartość zawartych umów, obejmując nawet zamówienia o wartościach niższych od progu bagatelności.

Strukturę zamówień in-house o wartościach przekraczających progi unijne przedstawia wykres 2 . Liderem w tej grupie są zamówienia udzielane na odbiór i zagospodarowanie odpadów. Z mocy obowiązujących przepisów wynika, że za gospodarkę odpadami odpowiedzialna jest administracja samorządowa, która corocznie stanowi największą grupę zamawiających. W roku 2018 udział w strukturze zamawiających, administracji samorządowej oraz jednostek organizacyjnych administracji samorządowej stanowił odpowiednio 31,39 i 19,53\% [UZP 2017; 30]. 

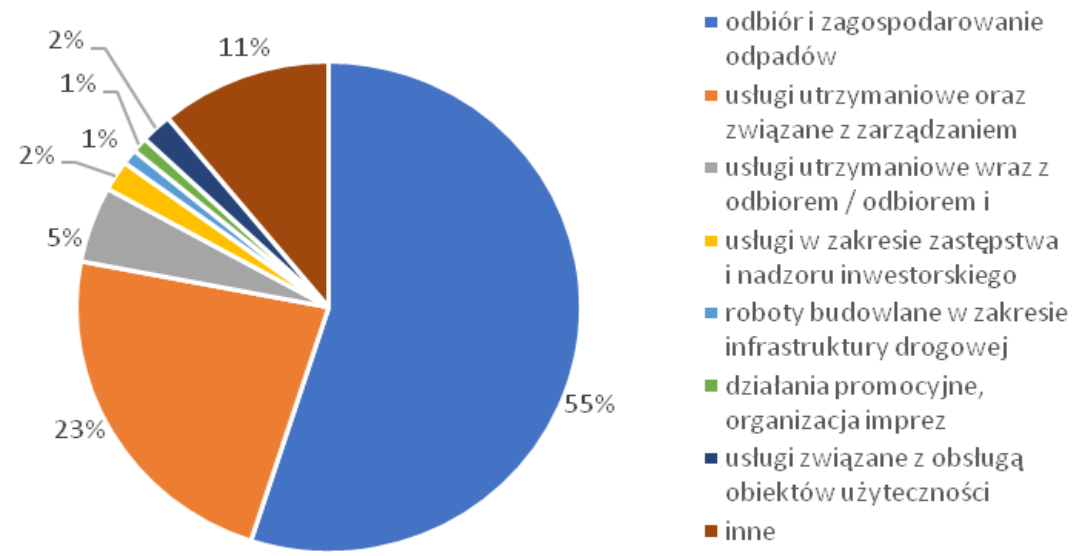

Wykres 2. Struktura zamówień in-house o wartościach przekraczających progi unijne w roku 2018

Źródło: UZP 2017.

Według danych opublikowanych przez UZP, w roku 2018 zamawiającym wykorzystującym formułę in-house była administracja samorządowa (95\%) i jednostki organizacyjne administracji samorządowej (3\%). Udzielono w tej formule 263 zamówień biuletynowych na usługi, głównie odbiór odpadów komunalnych. $\mathrm{W}$ zakresie zamówień unijnych, wykorzystując dane z przesłanych do Prezesa UZP zawiadomień o wszczęciu postępowania ustalono, że w roku 2018 udzielono 71 zamówień na usługi wywozu i zagospodarowania odpadów, w których tryb zamówienia z wolnej ręki uzasadniono zamówieniem in-house [2017: 143].

Sprawozdawczość jednoznacznie wskazuje, że obszarem wykorzystującym dodatkową, wprowadzoną w roku 2017, możliwość zastosowania najbardziej niekonkurencyjnego trybu udzielania zamówień, jakim jest zamówienie z wolnej ręki są usługi na wywóz i zagospodarowanie odpadów komunalnych, a rodzajem zamawiającego, wykorzystującego tę formułę, administracja samorządowa.

Postawiono pytanie badawcze, czy wyłączenie konkurencji, w obszarze zamówień in-house, o ile ma znaczenie, wpływa na finanse publiczne? Oraz czy wyłączenie konkurencji wpływa na warunki zawierania umów i czy te warunki skutkują zmianami w budżecie samorządowym.

Przyjęcie stanowiska, że zamówienie $\mathrm{z}$ wolnej ręki nie wpływa negatywnie na warunki zawieranych umów, podważyłoby racjonalność wprowadzania regulacji dotyczących udzielania zamówień publicznych, które obowiązują we wszystkich wolnorynkowych gospodarkach demokratycznych krajów świata.

Odpowiedź na drugie pytanie jest jednoznaczna. Zgodnie z obowiązującymi regulacjami prawnymi, wzrost cen usług związanych z wywozem i zagospodarowaniem odpadów nie wpływa na finanse podmiotów publicznych. W przypadku 
konieczności poniesienia wyższych kosztów przez samorząd, w związku z realizacją umowy na wywóz i zagospodarowanie odpadów, dodatkowe koszty przeniesione zostaną w całości na mieszkańców [Dz.U. 2019, poz. 2010]. Co więcej, samorząd może także przenieść na mieszkańców koszty realizacji celów wtórnych zamówienia, o ile takie założy w procedurze. Ponieważ, jak wspomniano wcześniej koszty te są w praktyce niewymierne, zamawiający może to robić bez żadnych konsekwencji. Według danych przedstawionych na wykresie 1, samorządy wykorzystują tę możliwość. Uzyskują w ten sposób bezkosztowe obniżenie swojej działalności, np. poprzez ograniczenie liczby osób bezrobotnych, które dodatkowo, nie będąc już obciążeniem finansowym gminy, po aktywizacji zawodowej, stają się płatnikiem podatku dochodowego, zasilającego jej budżet.

Pomimo obszernej literatury dotyczącej zamówień publicznych, brak jest badań ekonomicznych w zakresie wyjaśniania przyczyn wpływających na ich efektywność lub są to badania w dużej mierze opóźnione. Szczególnie dotyczy to analiz prowadzonych w wybranych środowiskach, takich jak gminy czy regiony kraju [Saussier i Valbonesi 2018: 1-4].

\section{OCENA EFEKTYWNOŚCI ZAMÓWIEŃ UDZIELANYCH NA USŁUGI WYWOZU I ZAGOSPODAROWANIA ODPADÓW W LATACH 2015-2018}

Zasada uczciwej konkurencji, stanowiąca podstawę regulacji Pzp, zmusza wykonawców do ograniczania kosztów działalności własnej w celu utrzymania zdolności do oferowania realizacji zamówień na warunkach korzystniejszych od konkurencji. Wyłączenie tej zasady i wkalkulowanie w cenę oferty realnych kosztów i dodatkowej marży, wykonawcy-monopolisty, jest możliwe z uwagi na występującą lukę prawną. Wykonawca-monopolista na quasi zmonopolizowanym rynku, jakim są usługi wywozu i zagospodarowania odpadów, może ustalać cenę w oderwaniu od realiów rynkowych, ponieważ nie podlega on kontroli UOKiK, a samorządy, którym podmiot podlega i dla których świadczy usługi, nie ponoszą kosztów potencjalnie zawyżonych usług. $Z$ ich punktu widzenia, istotna jest skuteczność prowadzonej procedury, sprowadzająca się do podpisania ważnej umowy, w możliwie krótkim czasie i bez dodatkowych czynności administracyjnych, przy wyeliminowaniu potencjalnych skutków procedur odwoławczych.

Tryb zamówienia z wolnej ręki traktowany jest jako zamknięty, niekonkurencyjny, niezapewniający uzyskania ceny rynkowej, a w praktyce zamówień publicznych, przy nieuprawnionym zastosowaniu przez zamawiającego, skutkujący odpowiedzialnością kierownika zamawiającego, co najmniej przed Rzecznikiem Dyscypliny Finansów Publicznych. Nie podlega on także społecznej kontroli w odróżnieniu od trybów przetargowych [Brańko 2017: 8]. 
Z uwagi na objęcie formułą in-house tylko części rynku usług na wywóz i zagospodarowanie odpadów, możliwe jest przeprowadzenie badania efektywności udzielanych zamówień na pozostałym obszarze, który funkcjonuje na zasadach wolnorynkowych.

W przedmiotowej pracy, efektywność rozumiana jest jako oszczędność wydatkowanych środków publicznych, a jej miarą jest relacja ceny oferty do wartości szacunkowej zamówienia, która wyznacza tzw. wskaźnik strat [Szymańska i Szymański 2019: 317].

$$
W_{s t}=\frac{W N}{W Z}
$$

gdzie:

$W N$ - cena wybranej oferty (wartość zamówienia),

$W Z$ - wartość szacunkowa zamówienia (brutto).

Wskaźnik strat jest wskaźnikiem natężenia odpornym na zmiany w dynamice badanego zjawiska, który dla zamówień oszczędnych przyjmuje wartości mniejsze od 1. Skala potencjalnych oszczędności określona jest pięcioma zakresami wielkości, które przyjmuje wskaźnik strat:

- dla zamówień najbardziej oszczędnych przyjmuje on wartości mniejsze lub równe 0,3 ,

- dla zamówień umiarkowanie oszczędnych znajduje się $\mathrm{w}$ przedziale $(0,3 ; 0,6)$,

- dla zamówień o niewielkiej oszczędności przyjmuje wartości z przedziału $(0,6 ; 1)$,

- dla zamówień przynoszących niewielkie straty przyjmuje wartości z przedziału $(1 ; 1,3)$,

- dla zamówień przynoszących wysokie straty przyjmuje wartości powyżej 1,3 .

W pracy przeprowadzono analizę statystyczną w oparciu o dane $\mathrm{z}$ udzielonych zamówień w latach 2015-2018. Oznacza to w praktyce objęcie badaniem dwóch lat przed wprowadzaniem formuly in-house i dwóch lat po jej wprowadzeniu. Badanie przeprowadzono w oparciu o próbę losową 200 zamówień udzielonych w trybach konkurencyjnych. Objęcie badaniem dwóch okresów umożliwiło przeprowadzenie oceny w celu ujawnienia ewentualnych zmian $\mathrm{w}$ systemie po wprowadzeniu formuły.

Badanie empiryczne przeprowadzono w oparciu o dane publikowane w Biuletynie Zamówień Publicznych prowadzonym przez UZP. Dostęp do krajowej bazy ogłoszeń jest pełny, a zakres zbieranych poprzez formularze ogłoszeń umożliwia dostęp do informacji dotyczących: trybu udzielenia zamówienia, wartości 
szacunkowej zamówienia, liczby złożonych ofert na jedno zamówienie, ceny wybranej oferty oraz ceny najdroższej i najtańszej oferty.

Losowość próby zweryfikowano medianowym testem losowości próby, biorąc pod uwagę wartość szacunkową zamówienia [Domański 1990: 38]. Na poziomie istotności 0,05 brak było podstaw do odrzucenia hipotezy zerowej, że próba jest losowa.

Konkurencyjność liczona jest jako liczba złożonych ofert na jedno zamówienie. Wykorzystując metody estymacji przedziałowej, można twierdzić z prawdopodobieństwem 95\%, że przeciętna konkurencyjność w latach 2015-2018 oscylowała w przedziale od 1,61 do 1,94 ofert/zamówienie. W okresie przed wprowadzeniem formuły in-house (lata 2015-2016) przedział ten mieścił się w granicach od 1,77 do 2,23 ofert/zamówienie, a po wprowadzeniu (lata 2017-2018) od 1,23 do 1,6 ofert/zamówienie. Wartości wskaźnika strat w próbie z uwzględnieniem konkurencyjności przedstawia tabela 1. Strukturę konkurencyjności wylosowanej próby przed i po wprowadzeniu formuły in-house przedstawiają wykresy 3 i 4 .

W celu stwierdzenia, czy konkurencyjność zamówień udzielanych w okresie przed i po wprowadzeniu formuły in-house różni się w sposób istotny statystycznie, z uwagi na brak spełnienia warunku normalności rozkładu zmiennej, wykorzystano test nieparametryczny U Manna-Whitneya dla prób niezależnych. $Z$ obliczeń prowadzonych w programie IBM SPSS Statistics wynika, że na poziomie istotności 0,002 należy odrzucić hipotezę zerową, co oznacza, że różnice w konkurencyjności obu okresów są istotne statystycznie.

Tabela 1. Wskaźnik strat w badanej próbie w zależności od konkurencyjności i badanego okresu

\begin{tabular}{|c|c|c|c|c|c|}
\hline & & & & \multicolumn{2}{|c|}{ Wskaźnik strat } \\
\hline & & & & Średnia & Mediana \\
\hline \multirow[t]{8}{*}{ okres } & \multirow[t]{5}{*}{ 2015-2016 } & \multirow{5}{*}{$\begin{array}{c}\text { konkurencyj- } \\
\text { ność }\end{array}$} & 1 & .86 & .86 \\
\hline & & & 2 & .88 & .81 \\
\hline & & & 3 & .78 & .76 \\
\hline & & & 4 & .57 & .57 \\
\hline & & & 5 & .70 & .69 \\
\hline & \multirow[t]{3}{*}{$2017-2018$} & \multirow{3}{*}{$\begin{array}{c}\text { konkurencyj- } \\
\text { ność }\end{array}$} & 1 & .91 & .88 \\
\hline & & & 2 & .84 & .88 \\
\hline & & & 3 & 1.01 & .79 \\
\hline
\end{tabular}

Źródło: obliczenia własne. 


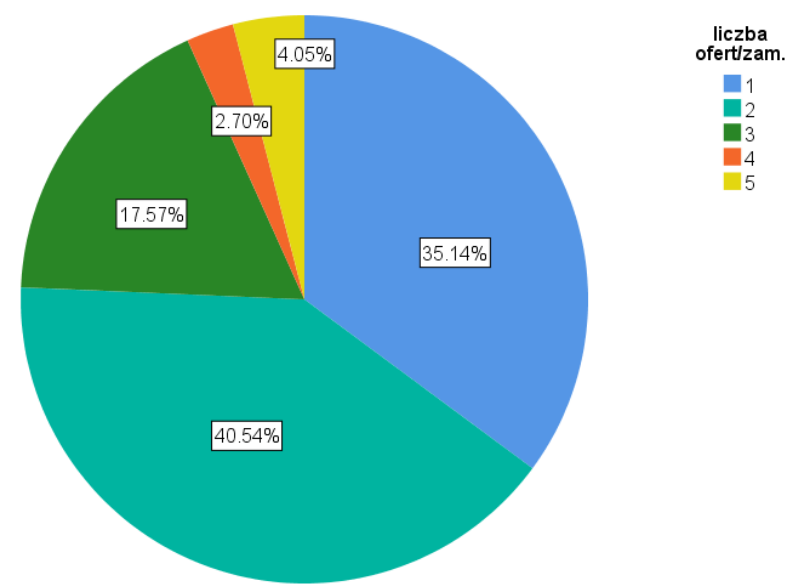

Wykres 3. Struktura konkurencyjności zamówień udzielonych w latach 2015-2016 Źródło: obliczenia własne.

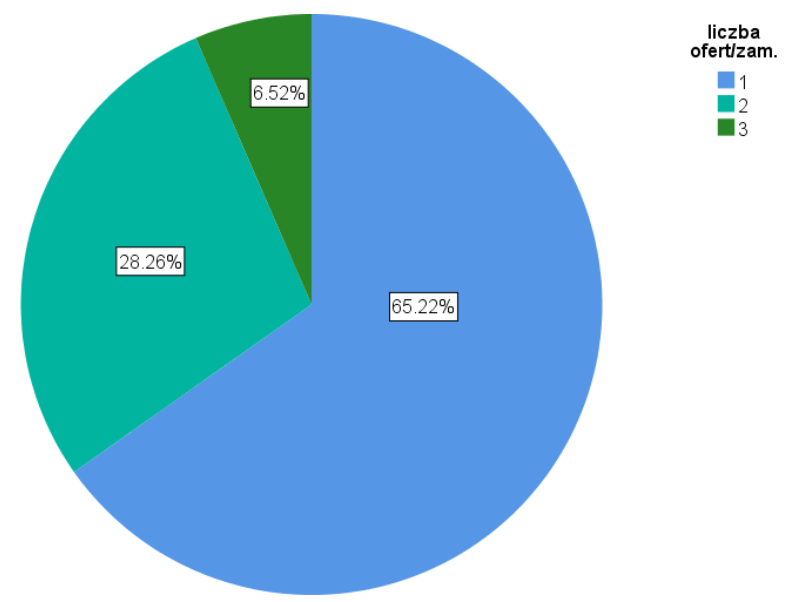

Wykres 4. Struktura konkurencyjności zamówień udzielonych w latach 2017-2018

Źródło: obliczenia własne.

Wykorzystując miarę korelacji liniowej Pearsona jak i rho Spearmana zbadano, czy istnieje zależność pomiędzy konkurencyjnością a wskaźnikiem strat. Obie miary wskazywały, że zachodzi słaba ujemna korelacja pomiędzy wskaźnikiem strat a konkurencyjnością, co oznacza, że obniżenie wskaźnika strat wywołane było wzrostem liczby składanych ofert/zamówienie. Obie miary są istotne statystycznie. Współczynnik korelacji Pearsona na poziomie istotności 0,05 
wyniósł $-0,18$, a współczynnik rho Spearmana wyniósł -0.31 na poziomie istotności 0,001 .

Postawione na wstępie pracy hipotezy zostały zweryfikowane pozytywnie. Pozornie drobna zmiana treści ustawy, dająca ograniczonej liczbie podmiotów przywileje, umożliwiające wyłączenie administracyjnych rygorów zawierania umów, wpływa negatywnie na cały badany rynek.

\section{PODSUMOWANIE}

Przeprowadzone badanie empiryczne wskazuje, że zmiana w systemie, polegająca na zwolnieniu części podmiotów z udziału w przetargach, nawet w ograniczonym zakresie, wpływa negatywnie na pozostałą część rynku, funkcjonującą w oparciu o zasady uczciwej konkurencji.

$\mathrm{Z}$ przeprowadzonego badania wynika, że wprowadzenie formuły in-house wywołało spadek konkurencyjności oraz wzrost wskaźnika strat. W efekcie zmian systemowych nastąpił wzrost cen. Spadek konkurencyjności jest prawdopodobnie efektem nasycenia wykonawców-monopolistów, którzy zgodnie z regulacją zawartą w Pzp, w celu zachowania możliwości korzystania z tej formuły, mają bardzo ograniczone możliwości wykazywania aktywności zewnętrznej. Treść art. 67 ust. 13 ustawy Pzp wskazuje wprost, że ponad 90\% działalności kontrolowanej osoby prawnej, realizującej zamówienie w formule in-house musi dotyczyć wyłącznie wykonywania zadań powierzonych jej przez zamawiającego sprawującego nad nim kontrolę.

Ocena efektywności zamówień publicznych, udzielanych w trybach zamkniętych, takich jak m.in. zamówienie $z$ wolnej ręki nie jest prowadzona, gdyż $\mathrm{z}$ założenia procedura jest nieefektywna. $\mathrm{Z}$ powodu braku możliwości określenia punktu odniesienia, dla wartości zawartej umowy, która uzależniona jest bardziej od intencji podmiotów ją zawierających niż od warunków rynkowych, nie można wyznaczyć wskaźnika strat. Poziom ewentualnego zawyżenia ceny jest ograniczony możliwościami finansowymi zamawiającego.

Udzielanie zamówień wybranej grupie uprzywilejowanych wykonawców, może skutkować pojawieniem się „marży monopolisty”. Takie podmioty, wspierane środkami mieszkańców gminy, w sposób niekontrolowany przez rynek mogą podnieś zyskowność swojej działalności, bez wprowadzania zmian w funkcjonowaniu firmy. W ocenie zamawiającego, który podejmuje racjonalne decyzje, nie powinno być dezaprobaty na zawyżanie kosztów umów na wywóz i zagospodarowanie odpadów w formule in-house. Przede wszystkim jest on wyłącznie pośrednikiem, a płatność przeniesiona jest na mieszkańców, dodatkowo wzrost dochodów podmiotu to więcej środków dla gminy, np. w formie podatku. 
W praktyce wprowadzenie fromuły in-house spolaryzowało zamawiających na dwie grupy: podmioty zawierające umowy w trybie zamówienia z wolnej ręki, pozostawiające sobie pewną swobodę w kształtowaniu cen usług oraz podmioty zawierające umowy w drodze przeprowadzenia postępowań przetargowych, które z przyczyn systemowych stały się mniej efektywne. Jednocześnie obie grupy zamawiających, w różnym zakresie, stosują klauzule społeczne, które w całości finansują mieszkańcy gmin. Prawdopodobnie tak szerokie uwarunkowania udzielanych zamówień publicznych odpowiadają za duże zróżnicowanie cen opłat za odbiór odpadów komunalnych w Polsce.

\section{BIBLIOGRAFIA}

Andała-Stępkowska J., Bereszko W., 2018, Prawo zamówień publicznych w praktyce, Wolters Kluwer, Warszawa.

Brańko B., 2017, Zamówienia in-house w polskiej ustawie Prawo zamówień publicznych, UZP, Warszawa.

Domański Cz., 1990, Testy statystyczne, PWE, Warszawa.

Murray J.G., 2009, Improving the validity of public procurement research, „International Journal of Public Sector Management", vol. 22(2).

NIK, https://www.nik.gov.pl.

Nowicki J.E., 2018, Prawo zamówień publicznych. Komentarz, Wolters Kluwer, Warszawa.

Nowicki P., 2013, Efektywne zamówienia publiczne jako rezultat stosowania nowego podejścia do zamówień publicznych, PARP, Warszawa.

Pokrzywniak J., Baehr J., Kwieciński T., 2006, Wprowadzenie do systemu zamówień publicznych, UZP, Warszawa-Katowice.

Saussier S., Valbonesi P., 2018, Public Procurement-new theoretical and empirical developments, „Economia e Politica Industriale”, vol. 45.

Szymańska A., Szymański J., 2019, Efektywność zamówień publicznych na ubezpieczenia realizowanych przez gminy w Polsce w latach 2016-2018, [w:] I. Kwiecień, P. Kowalczyk-Rólczyńska, Ubezpieczenia. Wyzwania rynku, C.H. Beck, Warszawa.

Szymański J., 2016, Aukcja elektroniczna w zamówieniach publicznych udzielanych przez publiczna stużbę zdrowia, „Annales H - Oeconomia”, vol. L(4).

UZP, 2017, Sprawozdanie Prezesa UZP o funkcjonowaniu systemu zamówień publicznych $w 2018 \mathrm{r}$.

Dyrektywa Parlamentu Europejskiego i Rady 2014/24/UE z dnia 26 lutego 2014 r. w sprawie zamówień publicznych.

Rozporządzenie delegowane Komisji (UE) 2019/1828 z dnia 30 października 2019 r. zmieniające dyrektywę Parlamentu Europejskiego i Rady 2014/24/UE w odniesieniu do progów dotyczących zamówień publicznych na dostawy, usługi i roboty budowlane oraz konkursów.

Rozporządzenie Ministra Rozwoju z dnia 16 grudnia 2019 r. w sprawie kwot wartości zamówień oraz konkursów, od których jest uzależniony obowiązek przekazywania ogłoszeń Urzędowi Publikacji Unii Europejskiej Dz.U. 2019, poz. 2450.

Ustawa z dnia 13 wrzesnia 1996r. o utrzymaniu czystości i porządku w gminach, Dz.U. 2019, poz. 2010.

Ustawa z dnia 22 czerwca 2016 r. o zmianie ustawy - Prawo zamówień publicznych oraz niektórych innych ustaw, Dz.U. 2016, poz. 1020.

Ustawa z dnia 29 stycznia 2004 r. Prawo zamówień publicznych, Dz.U. 2019, poz. 1843. 
[www1] www.energystar.gov [dostęp 18.03.2020].

[www2] www.nik.gov.pl/aktualnosci/nik-o-stosowaniu-klauzul-spolecznych-w-nbsp-zamowieniach-publicznych.html [dostęp 8.02.2020].

[www3] www.uzp.gov.pl/baza-wiedzy/zrownowazone-zamowienia-publiczne/spoleczne-zamowienia/przydatne-informacje/klauzule-spoleczne [dostęp 15.02.2020].

\title{
THE IMPACT OF THE IN-HOUSE FORMULA ON THE EFFECTIVENESS OF CONTRACTS AWARDED BY THE LOCAL GOVERNMENT ADMINISTRATION
}

\begin{abstract}
In 2017, the national public procurement system was enriched with a new formula extending the range of statutory exclusions, known as in-house procurement. This is a new premise that entitles the contracting authority to withdraw from the application of the procurement procedures laid down by law. It enables the contractor to retain monopoly in the area of orders given by the entity which controls it. Due to the specifics of the formula that creates a quasi monopolized market, a study was conducted to identify changes in competitiveness and effectiveness of contracts awarded. Due to the structure of contracts awarded in the in-house formula, the focus was on waste collection and management services.

The changes on the market of considered services were identified, which were caused by the application of the formula.
\end{abstract}

Keywords: public procurement, social clauses, in-house formula. 